Вісник Національного університету “Львівська політехніка”. Серія "Проблеми економіки та управління"

T. 4, № 1, 2020

UDK 911.3; 330.34(477):502.17:332.142.6; 504.062.2:628.5

JEL Classification Code O 13, Q21

N. I. Horbal, M.Ye. Adamiv, A.S. Chumak

Lviv Polytechnic National University,

Department of Foreign Trade and Customs

\title{
ADAPTATION OF CIRCULAR ECONOMY PRINCIPLES TO WASTE MANAGEMENT IN UKRAINE
}

\author{
https://doi.org/10.23939/semi2020.01.159 \\ (C) Horbal N. I., Adamiv M. Ye., Chumak A. S., 2020
}

In the field of waste management, Ukraine is far behind the EU countries, which is, in particular, a consequence of the existing linear model of the economy, and creates significant risks for the environment and the population. The need to search for new sources of sustainable development in the context of qualitative and quantitative constraints on natural resources and environmental problems actualizes the implementation of the circular economy model, which envisages energy conservation, regenerative green consumption and production for sustainable development, following the example of the $\mathrm{EU}$, which is a global leader in its implementation.

The EU Directive 2008/98/EC on waste (2008) enshrined in legislation 5 steps for waste management: from the most desirable (waste prevention, preparing for reuse) through the recycling and recovery to the least desirable - waste disposal. Instead, in Ukraine waste disposal is the most popular waste management measure, - over $7 \%$ of the country's territory is landfilled, and only $3 \%$ of all waste is recycled. At present, Ukraine is ranked 9th in the world by the amount of waste (3.5 billion tons annually). Unfortunately, only $8.6 \%$ of the world economy is circular and worldwide resource utilization is accelerating.

The process of circular economy implementation in a company is complex and, on the recommendation of BCG, should include: 1. Involvement of external stakeholders; 2. Consistent and strong support of senior management; 3. Explaining the concept and discussing the vision; 4. Developing a business model; 5. Employee training; 6. Involvement and empowerment of company departments; 7. Innovation in processes, products or business models; 8. Cooperation with external partners; 9. Identification of key performance indicators; 10. Forming and communicating social benefits.

In the context of European integration, Ukraine is recommended to use the already developed by the EU methodology, a clear algorithm for implementation of the circular economy, as well as successful examples of international companies (in particular, Gerrard Street, Thread, Enerkem, Ranault, Nespresso, Carlsberg, KMC, Ecolan). At the same time, the role of the state, a clear strategy for the implementation of circular principles (some legislative initiatives are already being implemented in Ukraine) and a radical change in public values are recognized as critical.

Keywords: waste, waste management, circular economy, closed-loop economy, sustainable development, linear economy, natural resources.

The article is prepared in the framework of the J. Monnet Module "EU competitiveness boosting: circular economy" (610641-EPP-1-2019-1-UA-EPPJMO-MODULE), which is being 


\section{N. I. Horbal, M. Ye. Adamiv, A. S. Chumak}

realized by the FTC Department with the support of the Erasmus + Programme of the European Union. The European Commission support for the production of this article does not constitute an endorsement of the contents which reflects the views only of the authors, and the Commission cannot be held responsible for any use which may be made of the information contained therein.

\section{Formulation of the problem}

In the field of waste management, Ukraine is far behind Europe, and the volume of waste generated, the poor state of landfills poses extreme risks for the environment and the population. The need to find new sources of sustainable development in the context of qualitative and quantitative limitations of natural resources and environmental problems makes it critical for Ukraine to adopt advanced world experience (in particular European) of circular economy functioning. Accordingly, the purpose of the article is to analyze the features of waste management in Ukraine today and the possibilities of adapting circular economy principles in this field, first of all, using EU experience.

\section{Analysis of recent research and publications}

Issues of waste management in the context of European integration of Ukraine has recently become the popular subject of domestic scientists research (for example, [1-2]) and legislative initiatives.

The model of circular economy (closed-loop economy), aimed at energy saving, regenerative environmentally friendly consumption and production, has emerged from the concept of sustainable development [3] and has been gaining popularity since the late 1970s. It has been actively researched in scientific sources, both foreign [4-8] and, in recent years, ukrainian [9-14]. Zvarych I. [9] describes goals of the circular economy, the vision of a new plastics economy in Europe, and presents methods for integrating industry into the circular process. Tymoshenko I. and Dronova O. [10] outline features of a circular economy, mechanisms for its introduction, the world successful practices with emphasis on the problem of solid waste recycling in Ukraine on the basis of circular principles. Krisovatyi A., Zvarych R. and Zvarych I. investigate the specifics of the circular economy in the context of globalization [11], the biophysical environment of the circular system, the integration of resources and the regeneration of the biosystem in the conditions of circular economy [12] and describe the specifics of the extended responsibility of a manufacturer in applying the concept of circularity [13]. Sergienko L. [14] describes the role of a state in the transition to a circular economy. Merkulova T., Kononova K. and Titomir O. [15] analyze applied aspects of a circular economy on the examples of two perspectives Ukrainian markets: renewable energy and waste processing.

\section{Main part}

The EU Directive 2008/98/EC on waste (2008) provides 5 steps of waste management. The most desirable is the prevention of waste generation, followed by the preparing for reuse, recycling and recovery. The least desirable step is waste disposal [16].

Instead, in Ukraine disposal is the most popular waste management measure. Today in Ukraine $95 \%$ of household waste is landfilled where it has been stored for decades (for comparison, in Sweden this amount is less than $1 \%$ ). In Ukraine, approximately 5.500 rubbish dumps are currently in operation, and morover 27.000 unauthorized dumps are generated annually. It is shocking that over $7 \%$ of Ukraine's land is occupied by landfills and only $3 \%$ of all waste is recycled. Most Ukrainian landfills are completely unsuitable for the prevention of environmental pollution, which is caused by unprocessed household waste [17]. Each year, about 350,000 tonnes of waste is generated in Ukraine. At present, $54 \mathrm{mln} \mathrm{m}^{3}$ of garbage have been accumulated at official and unofficial garbage collection sites in Ukraine.

According to the Ministry of Energy and Environmental Protection (Table), the largest pollutant in terms of waste generation is the Dnipropetrovsk region, which accounts for almost $70 \%$ of all waste, as more than 500 industrial enterprises are located there [18]. More than half of the enterprises included in the TOP100 pollutants rating are located in the territories of two regions: Dnipropetrovsk -33 and Donetsk -22 . 
Adaptation of circular economy principles to waste management in Ukraine

Rating of the regions of Ukraine which are the largest

pollutants of the environment in terms of waste generation in 2018 *

\begin{tabular}{|c|l|c|c|}
\hline \multirow{2}{*}{$№$} & \multirow{2}{*}{ Regions } & \multicolumn{2}{|c|}{ Waste volumes } \\
\cline { 3 - 4 } & & Physical volume, thousand tons & Share, $\%$ \\
\hline 1 & Dnipropetrovsk & 243598.81 & 69.14 \\
\hline 2 & Kirovohrad & 37902.02 & 10.76 \\
\hline 3 & Donetsk & 24110.24 & 6.84 \\
\hline 4 & Poltava & 19825.70 & 5.63 \\
\hline 5 & Zaporizhzhia & 5294.44 & 1.50 \\
\hline 6 & Mykolaiv & 2410.15 & 0.68 \\
\hline 7 & Lviv & 2139.31 & 0.61 \\
\hline 8 & Ivano-Frankivsk & 1969.80 & 0.56 \\
\hline 9 & Vinnytsia & 1782.15 & 0.51 \\
\hline 10 & Ternopil & 1651.80 & 0.47 \\
\hline 11 & Kharkiv & 1628.53 & 0.46 \\
\hline 12 & Cherkasy & 1484.59 & 0.42 \\
\hline 13 & Kyiv & 1394.00 & 0.40 \\
\hline 14 & Kyiv (city) & 973.73 & 0.28 \\
\hline 15 & Khmelnytsky & 900.53 & 0.26 \\
\hline 16 & Sumy & 852.21 & 0.24 \\
\hline 17 & Odesa & 728.53 & 0.21 \\
\hline 18 & Chernihiv & 717.39 & 0.20 \\
\hline 19 & Lugansk & 557.54 & 0.16 \\
\hline 20 & Volyn & 555.37 & 0.16 \\
\hline 21 & Zhytomyr & 486.14 & 0.14 \\
\hline 22 & Rivne & 484.22 & 0.14 \\
\hline 23 & Kherson & 392.44 & 0.11 \\
\hline 24 & Chernivtsi & 308.00 & 0.09 \\
\hline 25 & Transcarpathian & 186.26 & 0.05 \\
\hline & & $\mathbf{3 5 2} \mathbf{3 3 3 . 9 2}$ & $\mathbf{1 0 0 . 0}$ \\
\hline
\end{tabular}

* Excluding the temporarily occupied territory of the Autonomous Republic of Crimea, Sevastopol and part of the temporarily occupied territories of Donetsk and Luhansk regions. Source [18].

The total amount of pollution in 2018 in Ukraine [18]: 1. Emissions of pollutant substances 2.508 million tons; 2 . Discharges -952.136 million $\mathrm{m}^{3}$; 3 . Waste generation -352.333 million tons. The enterprises belonging to the TOP-100 pollutants formed 1.8 million tons of pollutant subatances emissions; 838.251 million $\mathrm{m}^{3}$ of discharges; 324.497 million tons of waste. At present, Ukraine is ranked 9th in the world among the countries with the highest waste volume [17].

Among the reasons that led to this are: poor manufacturing processes, the lack of innovative developments and materials in construction, the short product life cycle and the consumer mentality of Ukrainians. Most of these problems are the result of a linear model of the economy that involves: extraction of natural resources, production, use and, subsequently, the elimination of waste. It is now being replaced by an alternative model of economy, which is already being actively implemented in the leading countries of the world - circular or closed-loop economy.

The circular economy model focuses on the reuse of materials and aims at: reducing the cost of natural resources and energy for the production of goods; creating reusable goods; the use of materials that are easily recyclable, etc. Due to these principles, the circular economy makes it possible to use natural materials more efficiently, to develop products that will have a longer life cycle, and to increase significantly the profitability of production in the future. In Fig. 1 models of linear and circular economies are compared. 

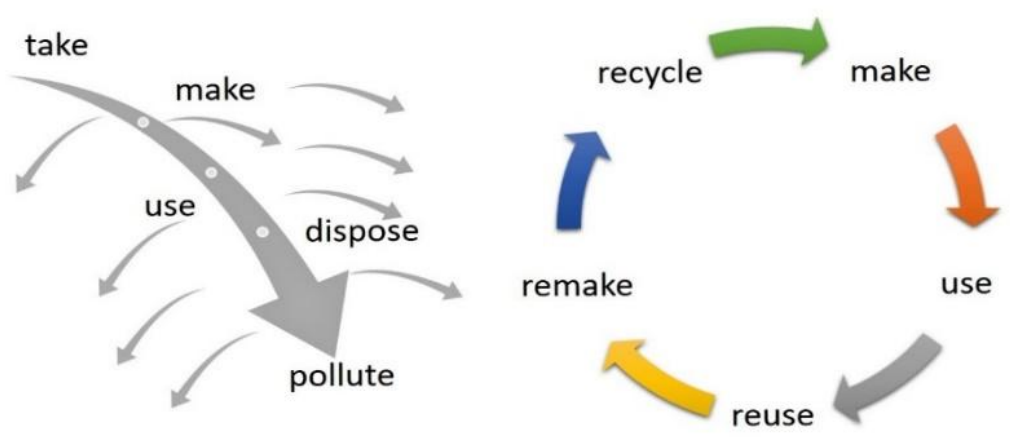

Fig. 1. Linear and circular economy models [19]

Today, there are many companies that have successfully adopted the principles of circular economy, and now they are good examples to follow [11, 20]:

1. Gerrard Street, a Dutch company which offers headphones as a service, since one of the popular business models in the circular economy is the service provision of goods. Their modular construction meets the circular principles, which makes it easy to repair or upgrade them. While the amount of e-waste continues to grow globally, this company demonstrates an alternative that makes it more competitive and resilient.

2. Thread, a Pittsburgh-based company, which has achieved a significant positive social impact through the circular principles. Thread attracts waste collectors in countries such as Haiti and Honduras to collect plastic bottles, which are recycled into fabrics. Thread is now partnering with such well-known brands as Reebok and Timberland. In addition to waste treatment, the company has provided jobs to locals.

3. Enerkem that uses innovative technologies for non-recyclable waste extracting carbon from the debris and then converting it into gas that can be used as biofuels and chemicals in everyday products.

4. Renault, which restores spare vehicle parts and successfully sell them with a 1-year warranty at a price of $50-70 \%$ of the new ones.

5. Nespresso that uses the coffee capsules return program. Spent coffee grounds is sold as a high quality fertilizer for landscapers, garden centers, municipalities and homeowners.

6. The Carlsberg Group, in collaboration with the Danish company ecoXpac, Innovation Fund Denmark and the Technical University of Denmark, is developing a fully biosoluble wood fiber beer bottle. The ultimate goal is to completely eliminate waste by creating eco-friendly products.

7. KMC, a Danish company that processes potato fiber residues into a protein-rich food additive.

8. Ecolan, a Finnish fertilizer producer, which produces organic Agra fertilizer using meat and bone meal. The raw material is processed into a powder, which is then mixed with other ingredients for the production of fertilizers, etc.

Unfortunately, according to The Circularity Gap Report 2020 [21] presented at the World Economic Forum in Davos, only 8,6\% of the world economy is circular. That is, only $8,6 \%$ of the 92,8 billion tonnes of minerals, fossil fuels, metals and biomass that are fed into the economy are reused annually. And global resource utilization is accelerating - it has tripled since 1970 and without global actions can double again by 2050 . Compared to the 2019 result ( $9 \%$ ), the trend is slightly improved.

The process of implementing a circular economy in a company is quite complicated and requires the involvement of all stakeholders at all stages of value creation. The Boston Consulting Group provides 10 recommendations for the implementation of the circular economy [22]:

1. Involvement of external stakeholders. Most of the companies surveyed state that clients are one of the most influential external groups, but government agencies, investors, and public organizations significantly affect the firm. It is important to involve external stakeholders, because the process of implementing a new economic model cannot happen without cooperation with them;

2. Consistent and strong support from senior management. Without it, the company is unable to obtain necessary human and financial resources. In addition, such active support inspires employees; 
3. Explaining the concept and discussing the vision. It is necessary to clarify to the middle management what the circular economy will mean for the company, both strategically and operationally. This will create a mutual understanding by all management levels;

4. Development of a business model. Given the high costs associated with the transition to a circular economy, business models are often focused on attracting new customers, strengthening relationships with existing customers, or capturing new markets;

5. Training employees. Before implementation, it is necessary to convey the vision to the staff and support it with training;

6. Engaging and empowering company departments. Departments take responsibility for the project and should be able to implement changes, so they should be involved at the very beginning of it;

7. Process innovations, followed by innovative products or business model innovations. It is least risky to start with the least destructive changes that will allow to form circular thinking, get first successes, and then adapt innovations in the business model;

8. Cooperation with external partners. To develop circular products, it is necessary to have a certain set of skills and new ways of thinking. Successful companies do not try to develop all of them on their own. Instead, they collaborate with various external partners from suppliers to research centers;

9. Identifying key performance indicators. The circular model can greatly improve competitiveness and profitability, but well-defined performance indicators are important;

10. Forming and communicating social benefits. Correct implementation of the circular model creates tangible business and social benefits: more efficient processes, attractive new products and services that increase customer and investor satisfaction.

These recommendations will help systematically and effectively implement the basic principles of circular economy at domestic companies, avoid losses and anticipate risks.

It is worth noting that one of the most important stakeholders in this case is the state - its support is able to facilite the adoption of the circular model in Ukraine. The best example is the EU that have developed a series of measures to support the development of the circular economy [23-24]. Countries such as Denmark, Finland, France, Germany, Greece, Italy, Luxembourg, the Netherlands, Slovakia, Slovenia and Belgium have successfully developed a "road map" for the adoption of the circular economy and are gradually implementing it. And countries such as France, the Netherlands, Poland, Portugal, Slovenia, Spain and Sweden even have tax incentives to implement the circular economy.

Therefore, for the development of a closed-loop economy in Ukraine, the state first of all must realize the importance of this model and develop a strategy for its implementation. In addition, following the example of European countries, using tax and other incentives, the state should encourage companies and individuals to adopt circular model.

In 2017, the Government approved a National Waste Management Strategy that implements European principles for the management of all types of waste: solid household, industrial, construction, agricultural, hazardous etc. Assistance in creating the National Strategy was provided by foreign experts under the auspices of the EBRD. The main tasks are the gradual transition of the country from the dominance of the disposal of solid waste to the sorting and separation for reuse, recycling or disposal at landfills that will meet EU requirements, as well as changing the treatment of waste as a valuable resource. The National Strategy states that by $2023,23 \%$ of the population will start sorting garbage, and by 2030 this figure should be $48 \%$. Now in Ukraine only $3 \%$ of all waste are recycled. Instead, according to the National Strategy, by 2023, recycling should increase to $15 \%$, and by 2030 to $30 \%$ due to the commissioning of waste sorting lines and refineries. 250-300 new waste collection centers and 90 waste sorting lines should be available in Ukraine. And the number of landfills must be reduced from 5.5 thousand to 100-150, which would meet EU standards.

In 2019, the Cabinet of Ministers approved the National Waste Management Plan by 2030. The reform proposed by the Government envisages the introduction of circular economy principles and extended producer responsibility, which should stimulate businesses to minimize and recycle waste, implement the aforementioned five-stage waste hierarchy operating in the EU. 


\section{N. I. Horbal, M. Ye. Adamiv, A. S. Chumak}

Unfortunately, there are still significant organizational and legislative challenges in implementation of the National Waste Strategy and Plan starting from the garbage sorting stage, not to mention the use of modern recycling technologies and financial resources for construction of specialized lines/enterprises [24].

However, circular economy is based not only on the improvement of waste management, production technologies and the use of resources, but also on a fundamental change in social values, thinking, and consumer behavior. And from this point of view, without exaggeration, the role of every citizen of Ukraine and the world is important.

\section{Conclusions and prospects for further research}

The huge amount of waste in Ukraine that poses high risks to the environment and the population is a consequence of the existing linear model of the economy, in particular: non-optimized production processes, lack of innovative developments and materials in industry, short product life cycle of goods and consumer mentality of Ukrainians. This actualizes the implementation of a circular or closed-loop economy model, following the example of European countries, which have been implementing such measures over the last decade. The key circular principles are: saving energy, regenerative green production and consumption. In the context of European integration, it was advised to use the already developed by the EU methodology, a clear algorithm for the implementation of the circular economy, as well as successful examples of international companies. Critical to this are the role of the state, a clear strategy for the adoption of circular principles (some relevant legislative initiatives are already being implemented in Ukraine) and radical changes in public values. Applying the experience of European countries, Ukraine is able to begin with improvement of waste management based on the implementation of circular principles, and then to move to higher levels of adaptation of the circular economy, which will contribute to solving environmental and resource problems that have been accumulating in the country for a long time. This may be the subject of further scientific research.

1. Войціховська А., Кравченко О., Мелень-Забрамна О., Панькевич М. (2019). Кращі європейські практики управління відходами (посібник). Видавництво “Компанія “Манускрипт””. Львів. 64 с.

2. Мельник О., Обіюх Н. (2019). Правові аспекти регулювання відносин у сфері поводження 3 побутовими відходами на муніципальному рівні в Україні та СС в умовах децентралізації. Підприємництво, господарство і право, № 3, С. 127-131.

3. Geissdoerfer, M. and Savaget, P. and Bocken, N.M.P. and Hultink, E.J. (2017). The circular economy a new sustainability paradigm?, Journal of cleaner production, 143, 757-768.

4. Ghisellini, P., Cialani, C., Ulgiati, S. (2016). A review on circular economy: the expected transition to a balanced interplay of environmental and economic systems. Journal of Cleaner Production, 114, 11-32.

5. Kirchherr, J., Reike, D., Hekkert, M. (2017). Conceptualizing the circular economy: An analysis of 114 definitions. Resources, Conservation and Recycling, 127, 221-232.

6. De Jesus, A., Antunes, P., Santos, R., Mendonça, S. (2017). Eco-innovation in the transition to a circular economy: An analytical literature review. Journal of Cleaner Production, 172, 2999-3018.

7. Kalmykova, Y., Sadagopan, M., Rosado, L. (2018). Circular economy From review of theories and practices to development of implementation tools. Resources, Conservation and Recycling, 135, 190-201.

8. Avraamidou, S., Baratsas, S. G., Tian, Y., Pistikopoulos, E.N. (2020). Circular Economy A challenge and an opportunity for Process Systems Engineering. Computers \& Chemical Engineering, 133, 106629.

9. Зварич, І. Я. (2019). Імплементація плану дій ЄС у сфері циркулярної економіки. Науковий вісник Ужгородського національного університету: серія: Міжнародні економічні відносини та світове господарство, Вип. 25, Ч. 1, С. 93-98.

10. Тимошенко I. П., Дронова О. Л. (2018). Циркулярна економіка для умов України. Формування ринкових відносин в Україні, № 9, С. 120-127.

11. Krysovatyy A., Zvarych I., Zvarych R. (2018). Circular economy in the context of alterglobalization. Journal of International Studies, 11(4), P. 185-200.

12. Зварич, Р., Зварич I. (2019). Інтеграція ресурсів та регенерація біосистеми в концепції розвитку циркулярної економіки. Вісник Тернопільського національного економічного університету, № 3, С. 74-86. 


\section{Adaptation of circular economy principles to waste management in Ukraine}

13. Зварич, Р., Зварич І. (2019). Розширена відповідальність виробника в концепції розвитку циркулярної економіки. Світ фінансів, № 3, С. 76-86.

14. Сергієнко, Л. В. (2017). Держава як інститут забезпечення реалізації положень циркулярної економіки. Інвестиції: практика та досвід, № 8, С. 117-125.

15. Merkulova T., Kononova K. and Titomir O. (2017). Development trends of circular economy: Case study of Ukraine. Rivista Di Studi Sulla Sostenibilita', Vol. 2017/2, iss. 2, 51-66.

16. Directive 2008/98/EC of the European Parliament and of the Council of 19 November 2008 on waste and repealing certain Directives. Available at: https://eur-lex.europa.eu/legal-content/EN/TXT/?uri= CELEX:02008L 0098-20180705.

17. Сталий розвиток компаній. Укрінформ (2020). Available at: https://www.ukrinform.ua/rubricpresshall/2877667-stalij-rozvitok-kompanij-slahi-rozvazanna-problem-zi-smittam-persij-krok-do-cirkularnoi-ekonomiki.html.

18. ТОП-100 найбільших підприємств-забруднювачів (2019). Міністерство енергетики та захисту довкілля. Available at: https://menr.gov.ua/news/34251.html.

19. Weetman, Catherine (2016). A circular economy handbook for business and supply chains: repair, remake, redesign, rethink. London, United Kingdom: Kogan Page, p. 25.

20. Циркулярна економіка заснована на логістиці (2018). Available at: https://asstra.com.ua/ukr/noviniasstra/2018/05/cirkulyarnaya-ekonomika/.

21. The Circularity Gap Report 2020. Available at: https://www.legacy.circularity-gap.world/2020.

22. Ten Steps Toward the Circular Economy (2018). Available at: https:/www.bcg.com/publications/ 2018/ten-steps-toward-circular-economy.aspx.

23. Circular Economy Package (2018). Available at: http://ec.europa.eu/environment/circular-economy/index_en.htm.

24. Overview of circular economy in Europe (2019). Available at: https://circulareconomy.europa.eu/ platform/sites/default/files/ecopreneur-circular-economy-update-report-2019.pdf.

25. Роздільне збирання відходів: чому Україна тупцює на місці? Укрінформ (2019). Available at: https://www.ukrinform.ua/rubric-society/2646409-rozdilne-zbiranna-vidhodiv-comu-ukraina-tupcue-na-misci.html.

1. Voitsikhovska A., Kravchenko O., Melen-Zabramna O., Pankevych M. (2019). Krashchi yevropeiski praktyky upravlinnia vidkhodamy (posibnyk) [Best European waste management practices (guide)]. Vydavnytstvo "Kompaniia "Manuskrypt"”, Lviv. 64 s.

2. Melnyk O., Obiiukh N. (2019). Pravovi aspekty rehuliuvannia vidnosyn u sferi povodzhennia $\mathrm{z}$ pobutovymy vidkhodamy na munitsypalnomu rivni v Ukraini ta YeS v umovakh detsentralizatsii [Legal aspects of regulation of municipal waste management relations at municipal level in Ukraine and the EU in the context of decentralization]. Pidpryiemnytstvo, hospodarstvo i pravo, 3, 127-131.

3. Geissdoerfer, M. and Savaget, P. and Bocken, N. M. P. and Hultink, E. J. (2017). The circular economy a new sustainability paradigm? Journal of cleaner production, 143, 757-768.

4. Ghisellini, P., Cialani, C., Ulgiati, S. (2016). A review on circular economy: the expected transition to a balanced interplay of environmental and economic systems. Journal of Cleaner Production, 114, 11-32.

5. Kirchherr, J., Reike, D., Hekkert, M. (2017). Conceptualizing the circular economy: An analysis of 114 definitions. Resources, Conservation and Recycling, 127, 221-232.

6. De Jesus, A., Antunes, P., Santos, R., Mendonça, S. (2017). Eco-innovation in the transition to a circular economy: An analytical literature review. Journal of Cleaner Production, 172, 2999-3018.

7. Kalmykova, Y., Sadagopan, M., Rosado, L. (2018). Circular economy From review of theories and practices to development of implementation tools. Resources, Conservation and Recycling, 135, 190-201.

8. Avraamidou, S., Baratsas, S. G., Tian, Y., Pistikopoulos, E. N. (2020). Circular Economy A challenge and an opportunity for Process Systems Engineering. Computers \& Chemical Engineering, 133, 106629.

9. Zvarych, I. Ia. (2019). Implementatsiia planu dii YeS u sferi tsyrkuliarnoi ekonomiky [Implementation of the EU Circular Economy Action Plan]. Naukovyi visnyk Uzhhorodskoho natsionalnoho universytetu: seriia: Mizhnarodni ekonomichni vidnosyny ta svitove hospodarstvo, 25(1), 93-98.

10. Tymoshenko I. P., Dronova O. L. (2018). Tsyrkuliarna ekonomika dlia umov Ukrainy [Circular economy for the conditions of Ukraine]. Formuvannia rynkovykh vidnosyn v Ukraini, 9, 120-127.

11. Krysovatyy A., Zvarych I., Zvarych R. (2018). Sircular economy in the context of alterglobalization. Journal of International Studies, 11(4), 185-200. 


\section{N. I. Horbal, M. Ye. Adamiv, A. S. Chumak}

12. Zvarych, R., Zvarych I. (2019). Intehratsiia resursiv ta reheneratsiia biosystemy v kontseptsii rozvytku tsyrkuliarnoi ekonomiky [Integration of resources and regeneration of the biosystem in the concept of development of circular economy]. Visnyk Ternopilskoho natsionalnoho ekonomichnoho universytetu, 3, 74-86.

13. Zvarych, R., Zvarych I. (2019). Rozshyrena vidpovidalnist vyrobnyka v kontseptsii rozvytku tsyrkuliarnoi ekonomiky [Extended responsibility of the manufacturer in the concept of development of circular economy]. Svit finansiv, 3, 76-86.

14. Serhiienko, L. V. (2017). Derzhava yak instytut zabezpechennia realizatsii polozhen tsyrkuliarnoi ekonomiky [The state as an institute for implementation of the circular economy provisions]. Investytsii: praktyka ta dosvid, 8 , $117-125$.

15. Merkulova T., Kononova K. and Titomir O. (2017). Development trends of circular economy: Case study of Ukraine. Rivista Di Studi Sulla Sostenibilita, 2, 51-66.

16. Directive 2008/98/EC of the European Parliament and of the Council of 19 November 2008 on waste and repealing certain Directives. Available at: https://eur-lex.europa.eu/legal-content/EN/TXT/?uri=CELEX: 02008L 0098-20180705.

17. Stalyi rozvytok kompanii (2020). [Sustainable development of companies]. Ukrinform. Available at: https://www.ukrinform.ua/rubric-presshall/2877667-stalij-rozvitok-kompanij-slahi-rozvazanna-problem-zi-smittampersij-krok-do-cirkularnoi-ekonomiki.html.

18. TOP-100 naibilshykh pidpryiemstv-zabrudniuvachiv (2019). [Top 100 largest polluting companies]. Ministerstvo enerhetyky ta zakhystu dovkillia. Available at: https://menr.gov.ua/news/34251.html.

19. Weetman, C. (2016). A circular economy handbook for business and supply chains: repair, remake, redesign, rethink. London, United Kingdom: Kogan Page, p. 25.

20. Tsyrkuliarna ekonomika zasnovana na lohistytsi (2018). [The circular economy based on logistics]. Available at: https://asstra.com.ua/ukr/novini-asstra/2018/05/cirkulyarnaya-ekonomika/.

21. The Circularity Gap Report 2020. Available at: https://www.legacy.circularity-gap.world/2020.

22. Ten Steps Toward the Circular Economy (2018). Available at: https://www.bcg.com/publications/ 2018/ten-steps-toward-circular-economy.aspx.

23. Circular Economy Package (2018). Available at: http://ec.europa.eu/environment/circular-economy/ index_en.htm.

24. Overview of circular economy in Europe (2019). Available at: https://circulareconomy.europa.eu/ platform/sites/default/files/ecopreneur-circular-economy-update-report-2019.pdf.

25. Rozdilne zbyrannia vidkhodiv: chomu Ukraina tuptsiuie na mistsi? Ukrinform (2019). Available at: https://www.ukrinform.ua/rubric-society/2646409-rozdilne-zbiranna-vidhodiv-comu-ukraina-tupcue-na-misci.html.

Н. І. Горбаль, М. С. Адамів, А. С. Чумак Національний університет "Львівська політехніка", кафедра зовнішньоекономічної та митної діяльності

\section{АДАПТУВАННЯ ПРИНЦИПІВ ЦИРКУЛЯРНОЇ ЕКОНОМІКИ ДО УПРАВЛІННЯ ВІДХОДАМИ В УКРАЇНІ}

(C) Горбаль Н. І., Адамів М. С., Чумак А. С., 2020

Доведено, що неефективне управління відходами в Україні, що є, зокрема, наслідком існуючої лінійної моделі економіки, створює значні ризики для навколишнього середовища і населення. Це актуалізус імплементацію моделі циркулярної економіки, яка передбачає енергозбереження, регенеративне екологічно чисте споживання і виробництво, за прикладом СС, що є глобальним лідером із її впровадження. Україні в умовах євроінтеграції запропоновано скористатись вже напрацьованою в ЄС методикою, чітким алгоритмом імплементації циркулярної економіки, а також успішними прикладами міжнародних компаній. При цьому критичними визнано роль держави, чітку стратегію впровадження циркулярних принципів (в Україні вже втілюються окремі законодавчі ініціативи) та кардинальну зміну суспільних цінностей.

Ключові слова: відходи, управління відходами, циркулярна економіка, економіка замкненого циклу, сталий розвиток, лінійна економіка, природні ресурси. 